\title{
EFEKTIVITAS PERLINDUNGAN HUKUM TERHADAP PERAWAT DALAM MEMBERIKAN ASUHAN KEPERAWATAN DI RUANG RAWAT INAP RSUD Dr. SOEDIRMAN KEBUMEN Oleh : Kasih Pujiutami ${ }^{142}$
}

\begin{abstract}
Nursing have role and strategies function in halty service for public and need be guaranteed too protection often expererence happen emergency circun stances to emergency measures should do not outharity for sake patient safety, will but malpractice pre sumption and low looking.

Constitution no thirty eight two thousand eighteen year about nursing for realize effetiveness low protection for nurse give nursing. Care by low research and discusion title is know noget effective because code ethics nursing portially basic profession require delegation of outhority for profession with besidesnurse mush do with write. outhority from proffesion with besides nurse because no get is low a wareness good nurse even nurse commission Dr soedirman haspital

Key Words : Low Protection effection for nursing
\end{abstract}

\begin{abstract}
ABSTRAK
Profesi keperawatan memiliki peran dan fungsi sangat strategis dalam pelayanan kesehatan kepada masyarakat dan perlu dijamin serta dilindunngi oleh undang-undang dalam memberikan asuhan keperawatan. Dalam praktik keperawatan sering mengalami terjadinya keaadaan darurat untuk melakukan tindakan medis yang seharusnnya bukan merupakan wewenang demi keselamtan pasien, akan tetapi praduga malpratik dan jeratan hukum mengintai.

Undang-Undang nomor 38 Tahun 2014 Tentang Keperawatan, untuk mewujudkan efektivitas perlindungan hukum terhadap perawat dalam memberikan asuhan keperawatan. Berdasarkan hasil penelitian dan pembahasan judul diatas diketahui belum efektif, karena didalam kode etik keperawatan sebagian dari standar profesi mengharuskan pelimpahan wewenang dari profesi lain ke perawat harus dilakukan secara tertulis

Kata Kunci: Efektivitas perlindungan hukum terhadap perawat
\end{abstract}

${ }^{142}$ RSUD Dr. Soedirman, Kebumen. kasihpujiutami@gmail.com, 081328731182 


\section{A. Pendahuluan}

Pembangunan kesehatan

sebagai bagian dari upaya pembangunan nasional yang menyeluruh, terarah, terpadu, dan berkesinambungan. Pembangunan kesehatan ditujukan untuk meningkatkan kesadaran, kemauan dan kemampuan hidup sehat bagi setiap orang dalam rangka mewujudkan derajat kesehatan yang optimal sebagai salah satu unsur kesejahteraan sebagaimana dimaksud dalam Pembukaan Undang-Undang Dasar 1945 dan kesehatan sebagai hak asasi manusia harus diwujudkan dalam bentuk pemberian berbagai upaya kesehatan kepada seluruh masyarakat melalui penyelenggaraan pembangunan kesehatan yang berkualitas dan terjangkau.

Kesehatan diartikan secara luas yang bersifat pemeliharaan health care baik secara preventif (pencegahan), represif (pemeliharaan), promotif (peningkatan), dan rehabilitatif (pemulihan). ${ }^{143}$ Upaya peningkatan taraf kesehatan manusia merupakan suatu usaha yang sangat penting dalam pembentukan sumber daya manusia yang berkualitas. Kemajuan dalam bidang kesehatan akan memberikan peluang bagi Indonesia untuk ikut berada dalam persaingan dunia yang semakin berkembang.

\footnotetext{
143 Hermien Hadiati Koeswadji. 1998. Hukum Kedokteran (Studi Tentang Hubungan Hukum Dalam Mana Dokter Sebagai Salah Satu Pihak), PT Citra Aditya Bakti, Bandung, hal. 86
}

Untuk menyelenggarakan pembangunan kesehatan yang berkualitas dan terjangkau, maka dibutuhkan sebuah profesi yang dinamakanperawat sebagai salah satu tenaga kesehatan dan patut disadari, bahwa profesi keperawatan memiliki peran dan fungsi sangat strategis dalam pembangunan bidang kesehatan, sedangkan pada sisi lain keperawatan adalah profesi dibidang kesehatan yang bertanggung jawab dan akuntabel terhadap pelayanan keperawatan kepada masyarakat dan perlu dijamin serta dilindungi oleh undang-undang demi terselenggaranya pelayanan keperawatan yang aman dan berkualitas.Berbicara pelayan kesehatan, maka tidak terlepas dari hal yang berkaitan dengan pelayanan keperawatan, mengapa, karena merupakan bagian integral dari pelayanan kesehatan yang dilakukan oleh perawat secara terus menerus berdasarkan keilmuan yang kokoh, kaidah etik dan nilai moral, serta standar profesi.

Berdasarkan hal tersebut, maka praktik keperawatan sebagai inti dari pelayanan keperawatan yang didasarkan pada kewenangan yang diberikan kepada perawat karena keahliannya, yang dikembangkan sesuai dengan kebutuhan kesehatan masyarakat, perkembangan ilmu pengetahuan dan tuntutan globalisasi. Untuk itu perlu memberikan perlindungan dan kepastian hukum kepada masyarakat dan perawat 
1167 | Jurnal Idea Hukum

Vol. 4 No. 2 Oktober 2018

Magister Hukum Fakultas Hukum Universitas Jenderal Soedirman

diperlukan pengaturan mengenai penyelenggaraan praktik keperawatan.

$$
\text { Dalam praktik pelayanan }
$$

kesehatan, perawat kerap kali menjadi objek praduga malpraktek. Pada tahun 2016 misalnya, Polres Singkawang Tengah melakukan penyidikan dugaan Malapraktek yang diduga dilakukan seorang perawat. Setidaknya sudah 35 orang diambil keterangan oleh satuan Reskrim Polres Singkawang. ${ }^{144}$ Di Bekasi, seorang perawat juga harus berurusan dengan kepolisian akibat praktik keperawatan. $^{145}$ Di Bantul, Kepala Dinas Kesehatan Bantul, Maya Sintowati Panji, mengatakan tim dari dinas kesehatan Bantul bakal menemui pihak-pihak terkait untuk mengungkap kasus dugaan malpraktik yang diduga dilakukan oknum perawat Puskesmas Dlingo 1. ${ }^{146}$ Begitupula dua perawat di Kebumen yang harus berurusan dengan Kepolisian karena di duga melakukan

${ }^{144}$ Hari, Dugaan Malpraktik

Perawat,

http://www.pontianakpost.co.id/dugaanmalpraktik-perawat, diakses pada tanggal 2 Oktober 2017.

${ }^{145}$ Darmo, Kaki Bayi Ini Membusuk, Diduga Lantaran Malpraktik Perawat RSUD, http://gobekasi.pojoksatu.id/2016/04/27/ kaki-bayi-ini-membusuk-didugalantaran-malpraktik-perawat-rsud/, diakses pada tanggal 2 Oktober 2017. ${ }^{146}$ Edy Setyawan, Dinas Kesehatan Bentuk Tim, Selidiki Dugaan Malpraktik di Puskesmas Dlingo, http://bantul.sorot.co/berita-5976-dinaskesehatan-bentuk-tim-selidiki-dugaanmalpraktik-di-puskesmas-dlingo.html diakses pada tanggal 2 Oktober 2017. malpraktek. ${ }^{147} \mathrm{PPNI} \quad$ Pusat

mencatat 33 perawat sejak tahun 2005 terkena tuntutan hukum karena melaksanakan tindakan medis untuk menolong masyarakat di daerah terpencil. Ironis sekali, satu sisi perawat dibutuhkan untuk memberikan pelayanan kesehatan, di sisi lain jeratan hukum mengintai perawat. Hal-hal demikian akan menimbulkan ketakutan bagi perawat dalam melaksanakan praktik keperawatan baik di sarana kesehatan umum maupun praktik mandiri. $^{148}$

Tumpang tindih pada tenaga keperawatan maupun dengan profesi kesehatan lainnya merupakan hal yang sering sulit untuk dihindari dalam praktik, terutama terjadi dalam keadaan darurat maupun karena keterbatasan tenaga di daerah terpencil. Dalam keadaan darurat, perawat yang dalam tugasnya sehari-hari berada disamping klien selama 24 jam, sering menghadapi kedaruratan klien, sedangkan dokter tidak ada. Dalam keadaan seperti ini perawat terpaksa harus melakukan

\begin{tabular}{|c|}
\hline $\begin{array}{l}\begin{array}{l}{ }^{147} \text { Feri, Diduga } \\
\text { Palpraktek } \\
\text { dipolisikan, }\end{array} \\
\text { http://maspolinnews...co.id/2017/01/brea } \\
\text { king-news-kebumen-gempar- } \\
\text { malpraktek- perawat.html, diakses pada } \\
\text { tanggal 2 Oktober 2017. } \\
{ }_{148} \text { Zifriyanthi Minanda Putri, UU } \\
\text { Keperawatan Sebagai Perlindungan } \\
\text { Hukum Bagi Praktik Keperawatan Di } \\
\text { Indonesia, } \\
\text { http://staff.unand.ac.id/zifriyanthi/2014/0 } \\
\text { 6/05/uu-keperawatan-sebagai- } \\
\text { perlindungan-hukum-bagi-praktik- } \\
\text { keperawatan-di-indonesia/, diakses } \\
\text { pada tanggal 2 Oktober 2017. }\end{array}$ \\
\hline
\end{tabular}


tindakan medis yang bukan merupakan wewenangnya demi keselamatan pasien. Tindakan ini dilakukan perawat tanpa adanya delegasi dan protapnya dari pihak dokter dan atau pengelola Rumah Sakit.

Keterbatasan tenaga dokter terutama di Puskesmas yang hanya memiliki satu dokter yang berfungsi sebagai pengelola Puskesmas, sering menimbulkan situasi yang mengharuskan perawat melakukan tindakan pengobatan. Tindakan pengobatan oleh perawat yang telah merupakan pemandangan umum di hampir semua Puskesmas terutama yang bearada di daerah tersebut dilakukan tanpa adanya pelimpahan wewenang dan prosedur tetap yang tertulis. Dengan pengalihan fungsi perawat ke fungsi dokter, maka sudah dapat dipastikan fungsi perawat akan terbengkalai dan tentu saja hal ini tidak dapat dipertanggungjawabkan secara professional. Perawat sebagai salah satu bagian dari kelompok tenaga kesehatan yang bersentuhan langsung dengan pelayanan kesehatan menjadi bagian yang tak terpisahkan dari isu hak atas kesehatan. Dari kacamata awam, perawat dapat dianalogikan sebagai halaman depan dari sebuah bangunan yang bernama "Pelayanan Kesehatan", karena merekalah tenaga kesehatan yang bersentuhan pertama kali dengan pasien dan memiliki waktu yang relatif lebih panjang untuk berhubungan dengan pasien dibanding dengan tenaga-tenaga kesehatan lainnya.
Kedudukan istimewa perawat dalam pemberian pelayanan kesehatan juga diatur melalui berbagai ketentuan peraturan perundangan terkait Tenaga Kesehatan. Dalam Pasal 73 ayat (1) Undang-Undang No. 29 Tahun 2004 Tentang Praktik Kedokteran dinyatakan larangan bagi penggunaan identitas berupa gelar atau bentuk lainnya yang menimbulkan kesan bahwa si pengguna adalah dokter yang telah memiliki surat tanda registrasi dan/atau surat izin praktik.

Berdasarkan latar belakang masalah di atas, makalah ini menggunakan metode yuridis sosiologi yaitu pendekatan yang menekankan pada pencarian-pencarian, data yang dikumpulkan bukan hanya yang disebut dalam hukum tertulis saja, akan tetapi diadakan observasi terhadap tingkah laku yang benar-benar terjadi. ${ }^{149}$ Pendekatan ini juga dilakukan untuk mengungkap hubungan timbal balik antara aspek hukum dan aspek non hukum. Dengan tujuan makalah ini adalah untuk menganalisis efektivitas perlindungan hukum terhadap perawat dalam memberikan asuhan keperawatan diruang rawat inap RSUD Dr. Soedirman Kebumen dan menganalisis kendala-kendala perlindungan hukum terhadap perawat dalam memberikan asuhan keperawatan diruang rawat inap RSUD Dr. Soedirman Kebumen.

\footnotetext{
${ }^{149}$ Ronny Hanintjito sumitro. Metodologi Penelitian Hukum. Ghalia Indonesia : Jakarta. 1998. Hal. 35.
} 


\section{A. Perumusan Masalah}

1. Bagaimanakah efektivitas perlindungan hukum terhadap perawat dalam memberikan asuhan keperawatan diruang rawat inap RSUD Dr. Soedirman Kebumen?

2. Apa yang menjadi kendala perlindungan hukum terhadap perawat dalam memberikan asuhan keperawatan diruang rawat inap RSUD Dr. Soedirman Kebumen?

\section{B. Metode Penelitian}

Dalam penelitian tesis ini, penulis menggunakan pendekatan sosiologis. Pendekatan sosiologis yaitu penelitian yang menggunakan fakta-fakta yang diambil dari perilaku manusia, baik perilaku verbal yang didapat melalui wawancara maupun perilaku nyata yang dilakukan melalui pengamatan langsung. ${ }^{150}$ Melalui pendekatan sosiolosis diharapkan efektivitas perlindungan hukum terhadap perawat dalam memberikan asuhan keperawatan diruang rawat inap RSUD Dr. Soedirman Kebumen dan kendala perlindungan hukum terhadap perawat dapat dianalisis secara komprehensif sesuai fakta-fakta yang ada.

Spesifikasi yang digunakan dalam penelitian ini adalah penelitian deskriptif analitis. Sumber data yang digunakan dalam penelitian ini adalah data primer dan sekunder. Metode Kualitatif adalah suatu tata cara penelitian yang menghasilkan data deskriptif-analisis.

D. PEMBAHASAN

1. Efektivitas Perlindungan Hukum Terhadap Perawat Dalam Memberikan Asuhan Keperawatan Diruang Rawat Inap RSUD Dr. Soedirman Kebumen

Berdasarkan UndangUndang Nomor 36 Tahun 2014 Tentang Tenaga Kesehatandan Undang-Undang Nomor 38 Tahun 2014 Tentang Keperawatan, maka kongkritisasi perlindungan hukum adalah sebagai berikut:

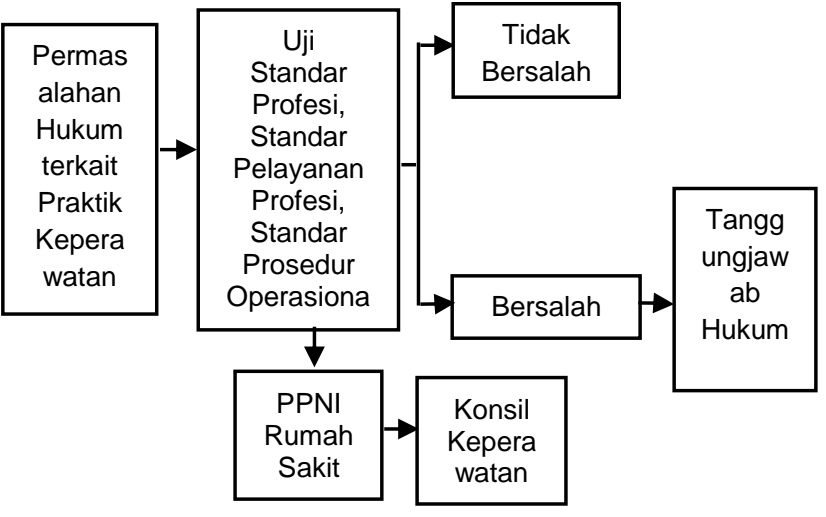

Berdasarkan skema tersebut, ketika terjadi permasalahan hukum terhadap 


pelayanan kesehatan yang
dilakukaan oleh perawat maka
tindakan medis perawat harus
diuji melalui tiga bahan uji yaitu
Standar Profesi dan Standar
Pelayanan Profesi akan diuji
PPNI (Persatuan Perawat

Nasional Indonesia), dan Standar

Prosedur Operasional yang

dibentuk oleh Rumah Sakit.

Undang-Undang Nomor 36

Tahun 2014 Tentang Tenaga

Kesehatan memberikan jaminan

terhadap semua tenaga

kesehatan dalam Pasal 78,

bahwa terhadap Tenaga

Kesehatan diduga melakukan

kelalaian dalam menjalankan

profesinya yang menyebabkan

kerugian kepada penerima

pelayanan kesehatan,

perselisihan yang timbul akibat

kelalaian tersebut harus

diselesaikan terlebih dahulu

melalui penyelesaian sengketa di

luar pengadilan sesuai dengan

ketentuan Peraturan Perundang-

undangan. Pasal ini membuka

kesempatan mediasi, sebelum

adanya penegakan hukum

melalui jalur perdata, dan pidana.

Efektivitas perlindungan

hukum terhadap perawat dalam

memberikan asuhan keperawatan

diruang rawat inap RSUD Dr.

Soedirman Kebumen dapat dilihat

dari respons terhadap peraturan-

peraturan hukum, sangat

tergantung dan dikendalikan oleh peraturan hukum yang berlaku, dari sanksi-sanksinya, dan dari seluruh kompleks kekuatan sosial, politik, dan lain sebagainya yang bekerja atas dirinya, serta dari umpan balik yang datang dari pemegang peran dan birokrasi. Pada dasarnya konteks perlindungan hukum dalam Undang-Undang Nomor 36 Tahun 2014 Tentang Tenaga Kesehatandan Undang-Undang Nomor 38 Tahun 2014 Tentang Keperawatan sudah memiliki bentuk yang jelas dan pasti namun dalam pelaksanaanya khususnya mengenai pelimpahan wewenang yang tidak sesuai dengan SOP dan bukan tanggung jawab perawat akan tetapi menjadi suatu kebiasaan dan kebutuhan.

Pada konteks perlindungan konsumen dalam Pasal 4 Undang-Undang Nomor 8 Tahun 1999 tentang Perlindungan Konsumen, konsumen memiliki hak-hak hukum yang pasti misalnya hak atas kenyamanan, keamanan, dan keselamatan dalam mengkonsumsi barang dan/atau jasa, hak untuk memilih barang dan/atau jasa serta mendapatkan barang dan/atau jasa tersebut sesuai dengan nilai tukar dan kondisi serta jaminan yang dijanjikan, hak atas informasi yang benar, jelas, dan jujur mengenai kondisi dan 
jaminan barang dan/atau jasa, hak untuk didengar pendapat dan keluhannya atas barang dan/atau jasa yang digunakan, hak untuk mendapatkan advokasi, perlindungan, dan upaya penyelesaian sengketa perlindungan konsumen secara patut dan lainnya.

Dalam konteks UndangUndang Nomor 36 Tahun 2014 Tentang Tenaga Kesehatan dan Undang-Undang Nomor 38 Tahun 2014 Tentang Keperawatan perlindungan hukum sudah diberikan secara jelas dan pasti akan tetapi kultur hukum yang menjadi pola kebiasaan tidak sesuai dengan peraturan yang sudah disyahkan. Ketidak jelasan hak atas perlindungan hukum, Kasi Keperawatan di RSUD Dr. Soedirman Kabupaten Kebumen, Saptono menyatakan bahwa:

Perlindungan hukum dalam tingkat yang paling tinggi secara operasional setelah Undang-undang dasar adalah undangundang. Payung hukum yang meregulasi perawat adalah UU Kesehatan nomor 36 tahun 2009, Permenkes nomor 148 tahun 2010 tentang praktik keperawatan, kemudian SK Menkes no. 729 tahun 2006, Permenkes no. 1796 tahun 2011 tentang sertifikasi, Sk Dirjen Yanmedik no. 00.06.5.1.311 dan MRA on
Nursing Services tahun 2006. Setelah lahirnya Undang-Undang 38 Tahun 2014 ternyata tetap sama, perlindungan hukum itu sudah dijamin secara jelas tinggal bagaimana perawat melaksanakan sesuai aturan yang sudah ada. ${ }^{151}$

Efektivitas perlindungan hukum terhadap perawat dalam memberikan asuhan keperawatan diruang rawat inap RSUD Dr. Soedirman Kebumen kurang dipahami dan di mengerti, karena kultur hukum yang tidak sesuai deangan subtansi hukum itu sendiri, dikarenakan pola pelimpahan wewenang yang bukan haknya terus dijalankan dan menjadi kebiasaan dengan mengabaikan konsekuensi hukum, sehingga menimbulkan tidakjelasan perlindungan hukum khususnya di RSUD Dr, Soedirman Kebumen. Dengan demikian pemberian perlindungan hukum akan terjadi apa adanya, yaitu secara spontanitas dimana dilakukan mediasi sebagai perlindungan hukum dasar untuk perawat. Mengapa dikatakan perlindungan hukum dasar, karena secara tradisi musyawarahlah yang dijadikan acuan dari penyelesaian masalah.

${ }^{151}$ Wawancara Kasi Keperawatan di RSUD Dr. Soedirman Kabupaten Kebumen, Saptono, pada tanggal 16 Januari 2018 
Entah mengeti atau tidak, jalur kompromi adalah proses pertama dan utama yang harus dilakukan Rumah sakit agar kasus tidak berkepanjangan.

Efektivitas perlindungan hukum terhadap perawat dalam memberikan asuhan keperawatan diruang rawat inap RSUD Dr. Soedirman Kebumen dapat ketahui dari respons terhadap peraturan-peraturan hukum, sangat tergantung dan dikendalikan oleh peraturan hukum yang berlaku,budaya hukum dari sanksi-sanksinya, dan dari seluruh kompleks kekuatan sosial, politik, dan lain sebagainya yang bekerja atas dirinya, serta dari umpan balik yang datang dari pemegang peran dan birokrasi. Pada dasarnya konteks perlindungan hukum dalam Undang-Undang Nomor 36 Tahun 2014 Tentang Tenaga Kesehatan dan Undang-Undang Nomor 38 Tahun $2014 \quad$ Tentang Keperawatan sudah memiliki bentuk yang jelas dan pasti akan tetapi implentasinya yang tidak sesuai karena sistem pelaksanaannya menjadi pola kebiasaan dan kebutuhan yang seharusnya bukan hak dan wewenang dari perawat.

2. Kendala Perlindungan Hukum Terhadap Perawat

DalaMemberikan Asuhan Keperawatan Diruang Rawat

\section{Inap RSUD Dr. Soedirman Kebumen}

Terdapat cukup banyak instrumen hukum yang dapat digunakan, tetapi kenyataannya masih terjadi pelanggaran terhadap pemberian sertifikat vaksinasi internasional. Hal ini tentunya perlu dikaji dengan mengetahui secara lebih nyata unsur-unsur sistem hukum yang bekerja di dalam masyarakat. Lawrence Meir Friedman mengemukakan tentang tiga unsur sistem hukum (there elements of legal system) dalam pelaksanaan suatu hukum. Ketiga unsur sistem hukum yang mempengaruhi bekerjanya hukum tersebut, yaitu :

1. Struktur hukum (Legal structure);

2. Substansi hukum (Legal substance);

3. Kultur hukum (Legal culture) $;^{152}$

Menurut Friedman, the structure of a system is its skeletal frame work; it is the permanent shape, the institutional body of the system the tough, rigid bones that keep the process flowing within bounds. Jadi struktur adalah kerangka atau rangkanya, bagian yang tetap

${ }^{152}$ Achmad Ali, 2002, Keterpurukan Hukum di Indonesia, Ghalia Indonesia, Jakarta, hlm. 7- 9. 
1173 | Jurnal Idea Hukum

Vol. 4 No. 2 Oktober 2018

Magister Hukum Fakultas Hukum Universitas Jenderal Soedirman

bertahan, bagian yang memberi

semacam bentuk dan batasan

terhadap keseluruhan. Dalam

sistem hukum yang berlaku di Indonesia, maka yang mencakup pada unsur struktur adalah struktur institusi-institusi penegak hukum seperti kepolisian, kejaksaan, pengadilan dan lembaga pemasyarakatan. ${ }^{153}$

Selanjutnya

menurut

Friedman $^{154}$, the substance is composed of substanctive rules and rules about how institutions should be have. Jadi, yang dimaksud substansi menurut Friedman adalah aturan, norma dan pola perilaku yang nyata manusia yang berada dalam sitem itu. Substansi disini termasuk pula the living law (hukum yang hidup) dan tidak hanya aturan yang ada dalam kitab undang-undang atau law in the book.

Kemudian sub sistem yang lain adalah kultur atau adat kebiasaan. $\quad$ Friedman $^{155}$, menyatakan mengenai kultur bahwa the legal culture, systemtheir beliefs, values, ideas, and expectations. (kultur hukum merupakan sikap manusia

153 Soerjono Soekanto, 2011, Faktor-Faktor Yang Mempengaruhi Penegakan Hukum, PT.Raja Grafindo Persada, Jakarta, hlm. 7

${ }_{155}^{154}$ Soerjono Soekanto, loc. cit

155 lbid., hlm. 9 terhadap hukum, sistem hukumkepercayaan, nilai, pemikiran serta harapannya). Legal culture refers, then, to those part of general culture-customs, opinions, ways of doing and thinking that bend social forces to ward or away from the law and in particular ways. (Kultur hukum adalah suasana pikiran sosial dan kekuatan sosial yang menentukan bagaimana hukum digunakan, dihindari atau disalahgunakan).

Hukum agar bisa berfungsi sebagai sarana rekayasa sosial bagi masyarakat biasa dan masyarakat pejabat sebagai pemegang law enforcement, maka dapat dipakai pendekatan dengan mengambil teori Robert Seidman yang menyatakan bahwa bekerjanya hukum dalam masyarakat itu melibatkan tiga kemampuan dasar, yaitu pembuat hukum (undang-undang), birokrat pelaksana dan masyarakat obyek hukum. Pelaksana hukum, perilakunya ditentukan pula peranan yang diharapkan daripadanya, namun bekerjanya harapan itu tidak hanya ditentukan oleh peraturanperaturan saja, melainkan juga ditentukan oleh faktor-faktor lainnya. Tenaga kesehatan berhak memperoleh perlindungan hukum dalam melaksanakan tugas sesuai dengan profesinya. 
Namun demikian terkadang bentuk perlindungan hukum yang diberikan terhambat, oleh faktor personal dan faktor sosial. Kasi Keperawatan di RSUD Dr. Soedirman Kabupaten Kebumen, Saptono menyatakan bahwa:

Perlindungan hukum dalam tingkat yang paling tinggi secara operasional setelah Undang-undang dasar adalah undangundang. Payung hukum yang meregulasi perawat adalah UU Kesehatan nomor 36 tahun 2009, Permenkes nomor 148 tahun 2010 tentang praktik keperawatan, kemudian SK Menkes no. 729 tahun 2006, Permenkes no. 1796 tahun 2011 tentang sertifikasi, Sk Dirjen Yanmedik no. 00.06.5.1.311 dan MRA on Nursing Services tahun 2006. Setelah lahirnya Undang-Undang 38 Tahun 2014 ternyata tetap sama, perlindungan hukum itu sudah dijamin secara jelas tinggal bagaimana perawat melaksanakan sesuai aturan yang sudah ada. ${ }^{156}$

Endang Widyo Wati selaku katim pelaksana keperawatan menambhakan bahwa, bahwa:

Perlindungan hukum tenaga keperawatan diperlukan, karena keperawatan adalah

${ }^{156}$ Wawancara Kasi Keperawatan di RSUD Dr. Soedirman Kabupaten Kebumen, Saptono, pada tanggal 16 Januari 2018

\begin{abstract}
pekerjaan yang sah, sehingga tindakan yang dilakukan tidak menjadikan perawat dikriminalisasikan. Nyatanya perlindungan hukum yang diatur UndangUndang 38 Tahun 2014 sudah jelas akan tetapi perawat masih melaksaksanakan hak profesi lain. Hal ini karena tidak ada kewajiban hukum yang tegas untuk mengatur kebiasaan perawat yang menjalankan haknya sehingga organisasi profesi menunjuk kuasa hukum, atau pembelaan terhadap perawat yang mengalami dugaan kasus malpraktik. ${ }^{157}$
\end{abstract}

Undang-Undang Nomor 36 Tahun 2014 Tentang Tenaga Kesehatan dan Undang-Undang Nomor 38 Tahun 2014 Tentang Keperawatan memasukan perlindungan hukum sebagai hak. Artinya sebagai hak, maka sudah menjadi konsekuensi logis terdapat pihak-pihak yang melaksanakan kewajiban tersebut. Undang-Undang Nomor 36 Tahun 2014 Tentang Tenaga Kesehatan dan Undang-Undang Nomor 38 Tahun 2014 Tentang Keperawatan tidak mengatur kewajiban organisasi profesi dalam membela perawat. Konteks peran menguji standar profesi dan standar pelayanan profesi justru mengaburkan kompetensi

${ }^{157}$ Wawancara dengan Endang WidyoWati selaku katim pelaksana keperawatan di Rumah Sakit Umum Daerah (RSUD) Dr. Soedirman, pada tanggal 20 Januari 2018 
1175 | Jurnal Idea Hukum

Vol. 4 No. 2 Oktober 2018

Magister Hukum Fakultas Hukum Universitas Jenderal Soedirman

organisasi profesi apakah sebagai pembela atau sebagai hakim yang menguji perbuatan perawat.

Menurut Friedman ${ }^{158}$, the substance is composed of substanctive rules and rules about how institutions should be have. Jadi, yang dimaksud substansi menurut Friedman adalah aturan, norma dan pola perilaku yang nyata manusia yang berada dalam sitem itu. Substansi disini termasuk pula the living law (hukum yang hidup) dan tidak hanya aturan yang ada dalam kitab undang-undang atau law in the book. Undang-Undang Nomor 36 Tahun 2014 Tentang Tenaga Kesehatan dan Undang-Undang Nomor 38 Tahun 2014 Tentang Keperawatan juga sudah mengatur kewajiban untuk mendampingi perawat dalam kasus-kasus hukum yang di jalani perawat. Undang-Undang Nomor 36 Tahun 2014 Tentang Tenaga Kesehatandan Undang-Undang Nomor 38 Tahun 2014 Tentang Keperawatan belum mewajibkan rumah sakit misalnya, untuk menyediakan pengacara, dalam mendampingi perawat. Begitupula organisasi profesi belum diwajibkan untuk menyediakan seorang pengacara.

$\begin{array}{cc}\text { Soerjono } & \text { Soekanto } \\ \text { menyatakan bahwa masalah }\end{array}$

${ }^{158}$ Soerjono Soekanto, loc. cit penegakan hukum sebenarnya terletak pada faktor-faktor yang mungkin mempengaruhinya. ${ }^{159}$ Undang-undang merupakan peraturan tertulis yang berlaku umum dan dibuat oleh penguasa pusat maupun daerah yang sah. Undang-undang merupakan perwujudan nilai-nilai yang disepakati pemerintah. Praktik penyelenggaraan hukum di lapangan ada kalanya terjadi pertentangan antara kepastian hukum dan keadilan, hal ini disebabkan oleh konsepsi keadilan merupakan suatu rumusan yang bersifat abstrak, sedangkan kepastian hukum merupakan suatu prosedur yang telah ditentukan secara normatif.

Dalam menerjemahkan substansi hukum dan kultur hukum, ternyata Lawrence M Friedman menggunakan teori H.L.A Hart, ia menyatakan bahwa:

Substansi dan kultur tersusun dari peraturanperaturan dan ketentuan mengenai bagaimana institusi-institusi itu harus berperilaku. H. L. A. Hart berpendapat bahwa, ciri khas suatu sistem hukum adalah kumpulan ganda dari peraturan-peraturan. Suatu sistem hukum adalah kesatuan dari "peraturanperaturan primer" dan "peraturan-peraturan sekunder." Peraturan hlm.8
${ }^{159}$ Soerjono Soekanto, Op cit., 
primer adalah normanorma perilaku; peraturan sekunder adalah norma mengenai norma-norma ini, bagaimana memutuskan apakah semua itu valid, bagaimana

memberlakukannya, Tentu saja, baik peraturan primer maupun sekunder adalah sama-sama output dari sebuah sistem hukum. Semua itu merupakan cara menjelaskan perilaku sistem hukum bila dilihat secara menyilang. Para pihak yang berperkara akan berperilaku atas dasar substansi yang membuahkan perkiraan yang direspon mereka. ${ }^{160}$

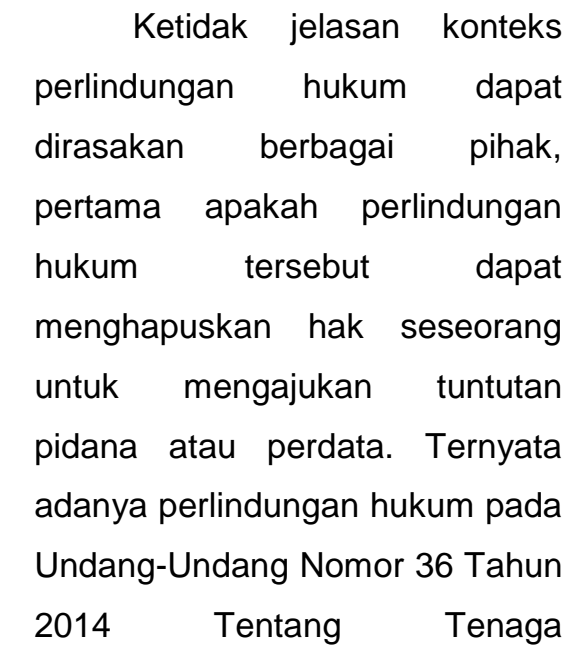
Kesehatandan Undang-Undang Nomor 38 Tahun 2014 Tentang Keperawatan tidak menghambat seseorang untuk mengajukan tuntutan hukum.

Selain karena budaya yang kurang sesuai khususnya perilaku pola kebiasaan pelimbahan wewenang dari profesi lian keperawat. Selaku pemegang

160 Lawrence M. Friedman, 2011, Sistem Hukum Perspektif IImu Sosial, Diterjemahkan oleh M. Khozim, Nusamedia, Bandung, hlm. 16 peran atau orang yang dikenakan hukum (adresat hukum), faktor lain yang menghambat perlindungan hukum terhadap perawat yaitu perawat itu sendiri dimna mau menerima limpahan wewenang. Rasa Eny Pratiwi selaku komite keperawatan menyatakan bahwa:

Perawat juga harus mengerti undang-undang dan hukum yang

berhubungan dengan kesehatan kepada umum, terutama undang-undang yang mengatur praktik keperawatan. Perawat haru $S$ juga memperhatikan fungsi dan tanggung jawabnya, seperti yang dijelaskan oleh hukum dan yang dikeluarkan oleh organisasi. Kenyataannya banyak perawat bahkan, kami komisi perawat banyak yang tidak mengerti hukum. Hal ini karena hukum tidak linier dengan bidang yang kami laksanakan. Dengan demikian masih diperlukannya penyuluhanpenyuluhan hukum guna menjelaskan hakikat perlindungan hukum terhadap perawat. ${ }^{161}$

Ruang lingkup suatu penegakan hukum adalah sangat luas, karena mencakup mereka yang secara langsung maupun tidak langsung berkecimpung dalam penegakan hukum. ${ }^{162}$

${ }^{161}$ Wawancara dengan . Rasa Eny Pratiwi selaku komite keperawatan di Rumah Sakit Umum Daerah (RSUD) Dr. Soedirman, pada tanggal 18 Januari 2018

${ }^{162}$ Ibid, hlm.19 
1177 | Jurnal Idea Hukum

Vol. 4 No. 2 Oktober 2018

Magister Hukum Fakultas Hukum Universitas Jenderal Soedirman

Faktor penegak hukum
memegang

Beberapa permasalahan yang

dihadapi penegak hukum antara

lain:

a. Tingkat aspirasi yang belum tinggi

b. Kegairahan yang sangat terbatas untuk memikirkan masa depan, sehingga sulit sekali untuk membuat suatu proyeksi.

c. Belum adanya kemampuan menunda pemuasan suatu kebutuhan tertentu, terutama kebutuhan materil.

d. Kurangnya daya inovatif yang sebenarnya merupakan pasangan konservatisme.

e. Keterbatasan

kemampuan untuk menempatkan diri dalam peranan pihak lain dengan siapa dia berinteraksi. ${ }^{163}$

Substansi yang ada seperti peraturan - peraturan, standar prosedur operasional belum belum sehigga akan menimbulkan struktur yang tidak dapat bergerak melalui kekuatan-kekuatan sosial lainnya, karena budaya pola kebiasaan pelimpahan wewenang saya kuat yang mengesampingkan konsekuesi hak dan kewajiban bagi perawat it sendiri.

Friedman menggambarkan bahwa ada kekuatan lainnya selain substansi dan struktur dalam menggerakan

${ }^{163} \mathrm{Ibid} ., \mathrm{hlm} .34-35$ hukum. Lawrence M Friedman

menyatakan bahwa :

Kultur perawat mengenai bagaimana sesuatu itu dipandang sebagai fakta atau tidak (kriteria realitas) dan bagaimana sesuatu itu ditentukan sebagai benar secara hukum atau tidak (kriteria kebenaran). Kriteria realitas yang dominan berlaku di RSUD DR. Soedirman Kabupaten Kebumen adalah realitas sosial yang berarti bahwa sesuatu itu dapat diterima sebagai fakta bila sesuai dengan kebiasaan yang telah ada atau opini umum yang berkembang di lingkungan RSUD DR. Soedirman Kabupaten Kebumen. Sementara itu, perawat RSUD DR. Soedirman Kabupaten Kebumen juga berpandangan dominan bahwa kebenaran lebih ditentukan oleh rasionalitas. Dengan kata lain, sesuatu itu dapat dipandang sebagai benar bergantung pada rasioanalitas kolektif di lingkungan RSUD DR. Soedirman Kabupaten Kebumen dan bila telah ditentukan melalui proses yang dapat diterima dalam saluran organisasi.

$$
\text { Budaya hukum adalah }
$$
tanggapan umum yang sama dari masyarakat tertentu terhadap gejala-gejala hukum. Tanggapan itu merupakan kesatuan pandangan terhadap nilai-nilai dan perilaku hukum. Asumsi 
perawat tentang perlindungan

hukum menunjukkan bahwa

perlindungan hukum merupakan

perlindungan yang diberikan oleh

rumah sakit. perlindungan hukum

diberikan kepada tenaga

kesehatan yang melakukan

tugasnya sesuai dengan standar

profesi tenaga kesehatan. Jadi

perawat diberikan pembelaan-

pembelaan atas tindakan yang telah dilakukan selama tindakantindakan tersebut dilakukan sesuai dengan prosedur. Komisi perawat RSUD Dr. Soedirman Kebumen memahami hukum secara parsial tidak utuh, dan cenderung praktis, sehingga perlindungan hak-hak perawat dalam perlindungan hukum tidak dilaksanakan secara maksimal.

\section{E. PENUTUP}

\section{Simpulan}

Berdasarkan hasil penelitian dan pembahasan maka dapat diambil suatu simpulan sebagai berikut:

Bentuk perlindungan hukum bagi perawat ada dalam tiga standar yaitu Standar profesi, Standar pelayanan, Standar operasional prosedur Perlindungan hukum terhadap perawat dalam memberikan asuhan keperawatan diruang rawat inap RSUD Dr. Soedirman Kebumen belum efektif, karena didalam kode etik keperawatan sebagian dari standar profesi mengharuskan pelimpahan wewenang dari profesi lain ke perawat harus dilakukan secara tertulis tetapi faktanya masih dilakukan dengan lisan saja dan di RSUD Dr. Soedirman belum ada Standar Operasional Prosedur tentang pelimpahan wewenang dari profesi lain ke perawat.

Kendala perlindungan hukum terhadap perawat dalam memberikan asuhan keperawatan diruang rawat inap RSUD Dr. Soedirman Kebumen antara lain:

a. Belum ada kesadaran hukum baik perawat bahkan komisi keperawatan RSUD Dr. Soedirman Kebumen tentang pelimpahan wewenang dari profesi lain keperawat, sejauh ini pelimpahan wewenang dari profesi lain ke perawat dilakukan secara lisan. Hal ini karena pelimpahan wewenang dianggap bukan merupakan kompetensinya.

b. RSUD Dr. Soedirman Kebumen belum mempunyai Standar Operasional Prosedur tentang pelimpahan wewenang dari profesi lain ke perawat meskipun pelimpahan wewenang dari perawat keperawat sudah ada dan diatur dalam UU No. 38 Tahun 2014 Tentang Keperawatan. 


\section{Saran}

1. Perlu adanya pengembangan sumber daya manusia yang berkompetensi dibidang hukum kesehatan untuk membantu, mendukung keseimbangan pelaksanaan tindakan medis, paramedis agar bisa berjalan sesuai dengan tupoksinya masing - masing sesuai dengan Undang-Undang dan SOP yang disyahkan di RSUD Dr. Soedirman

2. Pelimpahan wewenang yang tidak ada didalam Undang Undang dan SOP sebaiknya di delegasikan secara tertulis, dilakukan secara sistematis meskipun dalam keadaaan darurat sehingga tidak melanggar standar profesi.

\section{DAFTAR PUSTAKA}

Achmad Ali, 2002, Keterpurukan Hukum di Indonesia, Ghalia Indonesia, Jakarta

Edy Setyawan, Dinas Kesehatan Bentuk Tim, Selidiki Dugaan Malpraktik di Puskesmas Dlingo, http://bantul.sorot.co/berita-5976dinas-kesehatan-bentuk-timselidiki-dugaan-malpraktik-dipuskesmas-dlingo.html, diakses pada tanggal 2 Oktober 2017.

Darmo, Kaki Bayi Ini Membusuk, Diduga Lantaran Malpraktik Perawat RSUD, http://gobekasi.pojoksatu.id/2016/ 04/27/kaki-bayi-ini-membusukdiduga-lantaran-malpraktikperawat-rsud/, diakses pada tanggal 2 Oktober 2017

Feri, Diduga Malpraktek Perawat dipolisikan, http://maspolinnews..co.id/2017/0 $1 /$ breaking-news-kebumengempar-malpraktekperawat.html, diakses pada tanggal 2 Oktober 2017.

Koeswadji, Hermien Hadiati. 1998. Hukum Kedokteran (Studi Tentang Hubungan Hukum Dalam Mana Dokter Sebagai Salah Satu Pihak), PT Citra Aditya Bakti, Bandung.

Hari, Dugaan Malpraktik Perawat, http://www.pontianakpost.co.id/du gaan-malpraktik-perawat, diakses pada tanggal 2 Oktober 2017.

Friedman, Lawrence M. 2011, Sistem Hukum Perspektif IImu Sosial, Diterjemahkan oleh M. Khozim, Nusamedia, Bandung.

Sumitro, Ronny Hanintjito. 1998. Metodologi Penelitian Hukum. Ghalia Indonesia: Jakarta.

Soekanto, Soerjono 2011, Faktor-Faktor Yang Mempengaruhi Penegakan Hukum, PT.Raja Grafindo Persada, Jakarta.

Putri, Zifriyanthi Minanda. UU Keperawatan Sebagai Perlindungan Hukum Bagi Praktik Keperawatan Di Indonesia, http://staff.unand.ac.id/zifriyanthi/2 014/06/05/uu-keperawatansebagai-perlindungan-hukumbagi-praktik-keperawatan-diindonesia/, diakses pada tanggal 2 Oktober 2017. 